\title{
HEREDEROS DE IRLANDA AL SERVICIO DE ESPAÑA DURANTE LA GUERRA DE LA INDEPENDENCIA: EL CASO DEL PRIMER BATALLÓN DEL REGIMIENTO HIBERNIA
}

\author{
EVARISTO C. MARTÍNEZ-RADÍO GARRIDO \\ UNED ASTURIAS
}

\begin{abstract}
RESUMEN: Abordamos aquí cómo una unidad del Ejército español, pero con raíces irlandesas, se une al estallido de la Guerra de la Independencia en Asturias, primer territorio donde triunfó. Mostramos entonces qué había de tales raíces, sus dificultades en un ambiente revolucionario, el papel de la Junta del Principado, las sospechas de afrancesamiento, etc. Se trató de una unidad que ayudó realmente a componer el Ejército asturiano, distinguiéndose sus hombres en su servicio.
\end{abstract}

PALABRAS CLAVE: Irlanda, irlandés, Guerra de Independencia, Principado de Asturias, Ejército.

\section{HEIRS OF IRELAND AT THE SERVICE OF SPAIN DURING THE PENINSULAR WAR: THE FIRST BATTALION OF THE REGIMENT HIBERNIA}

\begin{abstract}
We will undertake to explain how a Spanish Army unit, but with Irish roots, got involved in the outbreak of the Spanish War of Independence in Asturias, the first territory in which it succeeded. We will highlight what still remained of those Irish roots, their difficulties due to the revolutionary context, the role of the Asturian Parliament, the suspicions of those that could be pro-French, and so on. Here indeed we have a military unit whose role gave significant stability to the Asturian Army, and its members made a name for themselves in its service.
\end{abstract}

KEY WORDS: Ireland, Irish, Peninsular War, Principality of Asturias, Army.

Recibido: 02-05-2013/ Aceptado: 03-09-2013 
Es conocido que la comunidad irlandesa tiene gran presencia y tradición en España. Siendo característica su integración, un lugar donde se hizo notar fue en su dedicación a las armas ${ }^{1}$, que llegó a dejar eco en buena parte de nuestra Historia. Hay reconocidos especialistas que se dedican a su estudio, como el equipo de investigación dirigido por Enrique García Hernán o los trabajos de María Begoña Villar García ${ }^{2}$. Por nuestra parte, pensamos que podría ser interesante analizar algún punto concreto en lugar de aspectos ya más tratados y, por tanto, conocidos. No obstante, aunque se trate de un estudio particular, no perderemos la visión general y entendemos que será ejemplo de la misma. Nos centraremos en parte de una unidad de origen irlandés, el Primer Batallón del Regimiento Hibernia, un siglo después de su conformación y coincidiendo con el momento trascendental en España como fue su Guerra de Independencia; qué pasó con él, si mantenía presentes y se dejaron sentir sus raíces. Y hemos de decir que localizar los expedientes o nombres concretos, más allá de una simple lista, no fue tarea fácil. En el caso que nos ocupa y como veremos, sus hombres se dispersaron en los 20 regimientos que se crearon en Asturias en los primeros inicios del conflicto, así como en otras unidades, y se vieron afectados por las reformas llevadas a cabo en aquellos años. Es decir, rastrear esta unidad se hizo especialmente complicado, más cuando las fuentes se pueden mostrar confusas ${ }^{3}$. Pero conseguimos llegar, y mostraremos, aspectos interesantes de por sí, tanto por las bases irlandesas, como por los históricos y políticos en el marco de la etapa trascendental comprendida entre 1808 y 1814. En el presente trabajo estamos ante un modelo de los muchos problemas de aquellos días, con una clara y ordenada exposición de la naturaleza de los problemas a afrontar: el ambiente revolucionario, el colapso del Estado, el papel de las juntas provinciales, sospechas de afrancesamiento, etc.

Lo que ya avanzamos y no es mayor secreto es que, de un origen netamente hibernés, con el paso del tiempo se configuró en una unidad española, aún con su carácter

\footnotetext{
${ }^{1}$ Sobre este particular es referencia ineludible GARCÍA HERNÁN, Enrique y RECIO MORALES, Óscar (coords.): Extranjeros en el Ejército. Militares irlandeses en la sociedad española, 1580-1818. Madrid, Ministerio de Defensa, 2007. Hay otras obras igualmente interesantes al respecto, aunque no de temática estrictamente militar, entre las que podemos destacar VILLAR GARCÍA, Mª Begoña (coord.): La emigración irlandesa en el siglo XVIII. Universidad de Málaga, 2000.

${ }^{2}$ Como visión y planteamientos generales sobre el estado de la cuestión, vid. VILLAR GARCÍA, M ${ }^{a}$ Begoña: "La contribución irlandesa al progreso de Europa en el siglo XVIII: militares, políticos y comerciantes", Baetica, 24 (2002), pp. 445-460. De la misma autora, no sólo para el caso irlandés: "Los extranjeros en la España moderna. Un campo historiográfico en expansión”, en Baetica, 29 (2007), pp. 425-441.

3 Es obligado mostrar nuestro agradecimiento al investigador D. José Luis Calvo Pérez, quien desinteresadamente nos facilitó la consulta de su interesantísimo y amplio archivo personal. Junto a él, reconocemos y también agradecemos las sugerencias y ayuda de $\mathrm{D}^{\mathrm{a}}$ Julia Smith sobre documentación en lengua inglesa, que tienen gran valor para nosotros, así como su apoyo a nuestra labor académica. Por otro lado, hubimos de buscar historiales y expedientes y aquí no podemos menos que mencionar la ayuda de mi capitán D. Agustín Pacheco y del Brigada Enrique Gallego Lázaro, por sus diligencias y molestias en los archivos generales militares de Madrid y de Segovia respectivamente.
} 
internacional debido a sus componentes, los cuales comprendemos que no se olvidaron de aquellas ${ }^{4}$. Hemos de decir que llegados al momento que nos ocupa, es evidente que el porcentaje humano con tal origen había descendido notablemente, con lo que, por supuesto, no se trata de una unidad "pura" irlandesa y debemos fijarnos más en su Plana Mayor. Por tanto, cuando tratemos ese componente a lo largo de estas líneas, se verá constreñido a un grupo reducido, pero no por ello menos importante. Con ello, sea por necesidades de efectivos y la dificultad de completarse con irlandeses o sea por una simple evolución de una unidad del Ejército español, se verá plenamente integrada en éste y no mostrará ningún problema en reorganizarse en las formas y modos en que lo hizo, por ejemplo, dicho primer batallón en el Principado; el Hibernia, junto con los Carabineros Reales enviados desde Valladolid, son considerados tropas españolas enviadas para sofocar una rebelión interna.

\section{LA INTEGRACIÓN MILITAR IRLANDESA EN ESPAÑA}

Si bien es conocido que los contactos y llegada de irlandeses a la Península son bastante anteriores, la etapa de máxima afluencia de isleños hacia España se situaría en las dos primeras décadas del siglo XVIII. En este punto, el Ejército fue el principal instrumento para vehicular a la nobleza de tal origen en el exilio y en aquellos años llegaron familias enteras como los O’Brien, O’Neill, Mahony, O’Connor u O’Doyle. Adaptando y tomando tales familias nobiliarias, reprodujo los esquemas sociales vigentes que constituyeron un reflejo del orden establecido. Su integración fue tal, que también se tradujo en compensaciones, cargos, empleos y títulos, algo que, por supuesto, interesaba a tal comunidad $^{5}$. No obstante, también podemos decir que no perdían de vista su ascendencia, aunque sin ser excluyente, manteniendo una postura integradora en el país de acogida. Un ejemplo de este tipo de integración “a la irlandesa” sería el de los hermanos O’Donnell D’Anhetan, también relacionados con el Regimiento Hibernia, quienes

\footnotetext{
${ }^{4}$ Con ello, la carga de aquella nación en sus filas no era la única. Siguiendo a José Fernández y González, estaba compuesto además por franceses, alemanes, italianos, húngaros y polacos. FERNÁNDEZ GONZÁLEZ, José: ;Asturias! De Oviedo a Covadonga. Oviedo, Establecimiento Tipográfico de Vicente Rubio, 1892 , p. 50.

${ }^{5}$ CABALLERO, Fernán: "No transige la conciencia”, en Relaciones. Colección de Autores Españoles, t. XIII. Leipzig, F.A. Brockhaus, 1868, pp. 92 y 93. VILLAR GARCÍA, Ma Begoña: "La contribución irlandesa...”, op. cit., pp. 449 y 450.
} 
"Tenían a otros irlandeses como sirvientes, y que conservaban la lengua irlandesa para entenderse entre ellos, aunque todos hablasen también un buen inglés con fuerte acento gaélico, debido, según Sir William [Parker Carroll], a haberlo aprendido en casa de un aya de esta nación. Por lo demás, estaban ya plenamente integrados en la sociedad española aunque mediatizados de alguna manera por su militancia exclusiva en las unidades irlandesas"

En el caso que nos ocupa, durante el siglo XVIII la proporción de irlandeses en la oficialidad no fue excesivamente alta $(0.22 \%)$, pero sí tuvo una presencia relevante en los altos mandos (brigadieres, mariscales de campo, tenientes generales y capitanes generales). Como expone el historial del Regimiento Hibernia, el generalato español recibió muchos de aquellos durante varias generaciones que, a nivel general, sirvieron a España con gran lealtad y, casados con mujeres españolas, formaron verdaderas dinastías militares como los O’Donell, O’Mulryan, O’Daly, O’Ryan, O’Farrill u O'Reilly ${ }^{7}$. Por supuesto que no todos los irlandeses se dedicaron al arte de la guerra. Es evidente que también se emplearon en otras actividades en las que destacaron, como pudo ser el comercio. No obstante y como el lector podrá comprender, al ser éste un trabajo de temática militar y ya estar tratado por otros especialistas, no nos detenemos en tal sentido.

Lo que sí resaltamos es el trato favorable hacia ellos, unidos en la fe católica. Ejemplos no faltan. Uno claro se daría en plena Guerra de Sucesión -como veremos, una contienda que nos interesa para nuestra unidad en concreto-, cuando se emite la Real Orden permitiendo la estancia de los irlandeses en estos Reinos y el trato con ellos de 27 de julio de 1705. La actuación destacada de algunas unidades hibernesas en el conflicto y el posterior arraigo y estabilidad de muchos de los oficiales al servicio de la Monarquía española, favoreció que el Rey les concediera su naturalización.

En este sentido y en la época, aparte del conocido lazo católico con Irlanda, también se aludía a otro como la sangre. Así es cómo nos fijamos en el primer punto de las capitulaciones por las que el regimiento Irlanda (entonces de Wauchope y anteriormente de Burck), pasó en 1715 al servicio de Felipe V, donde leemos: “cómo de tiempo inmemorial los españoles han reconocido a los irlandeses por sus descendientes y, como a tales, les

\footnotetext{
6 O'DONNELL Y DUQUE DE ESTRADA, Hugo: “Los O’Donnell D'Anhetan, seis hermanos en la Guerra de la Independencia”, en El General Castaños y su época (1757-1852). Sevilla, Cátedra General Castaños, 2010, p. 15. Enlazaría entonces con el caso del coronel del Regimiento Hibernia en su declaración de junio de 1808 por la que destacaría la importancia de sus raíces, de lo atávico, no del lugar de nacimiento, pues dice "ser originario de Irlanda, nacido en los Estados del Imperio de Austria".

7 Óscar Recio nos habla del corporativismo entre los irlandeses. Vid. RECIO MORALES, Óscar "El 'modelo irlandés' en los ejércitos de los Austrias y de los Borbones: continuidad y diferencias”, en E. García Hernán y O. Recio Morales (coords.): Extranjeros en el Ejército..., op. cit., pp. 216, 218-222.
} 
dieron la alternación de naturales"8. Esto sería por una tradición conservada tanto por isleños como por españoles por la cual estarían unidos ambos pueblos desde tiempos inmemoriales.

La idea general sería que una comunidad céltica habría pasado desde la Península a Irlanda a asentarse en ella y poblarla -la versión más aceptada es que proveniente de la franja cantábrica- ${ }^{9}$. Algunos relatos se remontan hasta el siglo XIV a.C. para tal hecho. Pero narraciones míticas aparte y evidencias de las conexiones del llamado Arco Atlántico, lo que se muestra claro es que hubo impronta por tales relaciones a lo largo del tiempo.

Es obvio que las consideraciones con esta comunidad no finalizaron con el primer Borbón español -ni en un Ejército que no perdió su carácter plurinacional-. En el caso del Hibernia, una de sus aspiraciones era "proporcionar a los jóvenes de la nobleza irlandesa, el poder seguir la honorífica carrera de las armas, a que su inclinación los impelía, sin abandono o perjuicio de la religión que profesaban". Los irlandeses y suizos formaron especialmente los Regimientos extranjeros y a lo largo de su existencia participaron en pie de igualdad respecto a las unidades netamente españolas, no sólo en la Península, sino en Ultramar, como pudo ser la América española ${ }^{10}$. En 1818 quedarán extinguidos.

\footnotetext{
8 Archivo Histórico de Asturias, Libros de Actas y de Documentos de la Junta General y Diputaciones del Principado, signatura 4, ff. 71 r. y 71 v. PABLO CANTERO, Antonio de: "Los regimientos irlandeses de Infantería en la Guerra de Sucesión", en La Guerra de Sucesión en España y América. Sevilla, Cátedra General Castaños, 2000, p. 403. VILLAR GARCÍA, Ma Begoña: "La contribución irlandesa...”, op. cit., p. 450. LARIO DE OÑATE, M ${ }^{a}$ del Carmen: "Irlandeses y británicos en Cádiz en el siglo XVIII", en Mª B. Villar García y P. Pezzi Cristóbal (eds.): Los extranjeros en la España Moderna, T. I. Málaga, Universidad de Málaga, 2003, p. 419. DOWNEY, Declan: "Catholicism, Milesianism and Monarchism: The facilitators of Irish Identification with Habsburg Spain”, en E. García Hernán y O. Recio Morales (coords.): Extranjeros en el Ejército..., op. cit., pp. 167 y ss.

${ }^{9} \mathrm{Y}$ así se recoge en la bibliografía de aquél país. Entre tantos, ponemos algunos ejemplos, como pueden ser: MOORE, Thomas: The History of Ireland, vol. I. París, Baudry's European Library, 1835; KEATING, Geoffrey: A complete History of Ireland, from de first colonizations of the island by Parthalon, to the anglo-norman invasion; collected and arranged from the most ancient records of Ireland, and from authentic foreign writers, vol. I. Dublín, John Barlow, 1811; BINNS, Jonathan: Miseries and beauties of Ireland, vol. II. Londres, Longman, Orme, Brown and Co., 1837.

${ }^{10}$ Sobre este caso, vid. MARTÍNEZ RUIZ, Enrique: "España y la América española a comienzos del siglo XIX. El pórtico de la emancipación”, en XLIII Jornadas de Historia Marítima. Emancipación de América, ciclo de conferencias diciembre de 2011, cuaderno monográfico no 64. Madrid, Instituto de Historia y Cultura Naval, 2011, pp. 21 y 25. Nos consta que hubo miembros del Hibernia que prefirieron asentarse en América, como el del teniente Andrés Creagh Ploves o los capitanes José Copenger y Federico Barón de Winterfeld. Archivo General de Simancas, Secretaría de Guerra, leg. 6840, exp. 54; leg. 6842, exp. 76; leg. 6855, exp. 41; leg. 6871, exp. 78, leg. 6878, exp. 41; leg. 6880, exp. 82; leg. 7058, exp. 51; leg. 7308, exp. 22. Precisamente sobre los hombres del Hibernia que se afincaban y tenían descendencia en América, vid. MARCHENA FERNÁNDEZ, Juan: "Los oficiales militares irlandeses en el Ejército de América”, en E. García Hernán y O. Recio Morales (coords.): Extranjeros en el Ejército..., op. cit., pp. 332-334.
} 


\section{LOS ORÍGENES DE LAS UNIDADES IRLANDESAS DEL XVIII Y EL CASO DEL HIBERNIA: IN OMNEM TERRAM, EXHIVIT SONUS EORUM ${ }^{11}$}

Efectivamente, como aludimos unas líneas más arriba, la afluencia hibernesa a España se remontaba a tiempo atrás. En nuestro caso, podemos decir que su gran antecedente sería el de la entronización de la reina Isabel I de Inglaterra en 1558. En ese momento, debido a las luchas entre católicos y protestantes, muchos isleños emigran fijando tal destino, donde se les daba cobijo. Así llegaron bastantes señores de aquellas tierras incluso seguidos de sus naturales vasallos, continuándose las migraciones en las etapas siguientes ${ }^{12}$. De hecho, durante el reinado de Felipe III se formaron seis tercios de Infantería de tal origen que fueron aumentando sus efectivos paulatinamente hasta llegar a un número de veintitrés junto con los escoceses en 1677. Sin embargo estas fuerzas fueron disminuyendo, con lo que en 1700 sólo subsistirá uno, el Tercio de O’Lalor, que se extinguirá en 1710. Pero no supondrá el fin de este componente humano en el Ejército español. Es más, la mencionada Guerra de Sucesión es un hito para nuestra unidad, pues a finales de 1709 comienzan a operar cuatro unidades de tal origen entre las que estaba el de Regimiento de Castelar, origen del Hibernia ${ }^{13}$.

Poco después, en la Real Ordenanza de 10 de febrero de 1718, quedaron especificadas las denominaciones fijas que debían llevar, y se nombraron como pertenecientes a la escala general del arma de Infantería a los regimientos irlandeses, en este caso observamos cinco: Ultonia (antiguo de Macauliffe); Irlanda (antiguo de Wauchope) ${ }^{14}$; Waterford (antiguo de D. Juan de Comeford); Limerick (antiguo de Vendôme o de D. Cornelio O’Driscoll) y el que nos ocupa, Hibernia (antiguo de Castelar), nombres que

\footnotetext{
11 Psalmo 18, vers. 4 que ostentaba en su orla.

12 LORENZO TENA, Antonio: “Una colonia irlandesa en la isla de La Palma durante el siglo XVIII”, Boletin Millares Carlo, 27 (2008), p. 84. CABALLERO, Fernán: "No transige la conciencia”, op. cit., p. 92. No obstante, siguiendo a Villar García, las migraciones irlandesas de la Edad Moderna se insertarían en unas corrientes migratorias más generales. Vid. VILLAR GARCÍA, Ma Begoña: "La contribución irlandesa...", op. cit., pp. 447 y 448.

${ }^{13}$ En su historial se recoge tal antigüedad, que sería la misma que la del Macauliffe (posteriormente Ultonia). Por su parte, figuran otros dos de ese mismo año, como son el del Duque de Liria y el de Juan de Comeford, con fecha de 13 de diciembre. Siguiendo lo expuesto por Fernán Caballero, en 1709 se formaron los regimientos de Hibernia y Ultonia y, más adelante, el de Irlanda. Mandaba estas fuerzas Jacobo Stuart, Duque de Werwick, hijo natural de Jacobo II y Arabela Churchill (hermana de Marlborough), quien fue el vencedor de la batalla de Almansa (1707) y tomó Barcelona. Sobre él y la relación irlandesa, vid. CABALLERO, Fernán: "No transige la conciencia", op. cit., p. 92. Si bien Pablo Cantero expone que ya en 1717 se contempló hacerlo con españoles debido a la dificultad contar con oriundos de Irlanda, hasta 50 hombres por compañía. ${ }_{14}$ Según recoge Pablo Cantero. En este punto la información es confusa, pues en el historial del Regimiento Hibernia y respecto a aquél, nos indica que había sido admitido como nuevo en 1766 con la denominación de "Cuerpo de Guardias de la Reina de Inglaterra" procedente de Francia. Más tarde sería cuando tome la denominación de "Irlanda". Junto a ello y antes de tal denominación, también figura como "Príncipe de Asturias", siendo su coronel el citado Wauchope. Los Cuerpos de Infantería irlandesa serían cinco por un tiempo, con los nuevos nombres de Irlanda, Hibernia, Ultonia, Waterford y Limerick.
} 
derivan de condados irlandeses o aluden a su isla de origen. De éstos, los de Limerick y Waterford causan baja como unidades en el Ejército español en 1734. El primero se contratará con el rey de Nápoles y el segundo reforzará con sus efectivos a los de Irlanda, Hibernia y Ultonia.

El Regimiento de Hibernia, si bien tiene su origen en tropas auxiliares al servicio de Luis XIV, se levantó al servicio de Felipe V el 1 de noviembre de 1709 en las villas de Cariñena y Longares, Reino de Aragón. Según parece, su creación pudo responder a que algunos oficiales al servicio del Rey Sol querían pasar a servir a su nieto, sea porque pensaran que tendrían más facilidades de prosperar "o bien atentos al común beneficio de la noble católica juventud de Irlanda”. Para ello, consultaron con el Caballero John Higgins, médico de Felipe V, quien favoreció tal pretensión, y se contó con la ayuda de José Patiño -facilitándole que fuera coronel su sobrino, el hijo del Marqués de Castelar, D. Lucas Patiño-. Creado mediante el sistema de concesión de patentes en blanco a los levantadores, a esta unidad se le autorizó a reclutar católicos irlandeses provenientes de los ejércitos ingleses en la Guerra de Sucesión ${ }^{15}$.

Hasta su disolución, operará en los conflictos en los que se verá envuelta España, tales como: la contienda sucesoria (1702-1714), campañas de Italia (1718-19), sitio de Gibraltar (1727-28), Orán (1732, 1791), Argel (1748, 1775), Portugal (1762, 1800), Colonia de Sacramento (1777), Luisiana, Florida, Cuba, Jamaica y Santo Domingo (1780-83), Rosellón (1793-95) y Guerra de la Independencia, que más nos interesa (1808-14), teniendo un lugar destacado en el Principado de Asturias. Si bien el 2 de marzo de 1815 todavía lo vemos como cuerpo de línea en la reorganización del Ejército de tal fecha, en 1818 se acabará extinguiendo refundiéndose en los batallones $1^{\circ}$ de Zamora, $2^{\circ}$ de Mallorca y $3^{\circ}$ de Jaén. Fue su último coronel D. Juan Antonio de Barutell ${ }^{16}$.

\footnotetext{
15 Vid. Archivo General Militar de Madrid, Historial del Regimiento Hibernia, ff. 1-5. PABLO CANTERO, Antonio de: "Los regimientos irlandeses...", op. cit., pp. 399-402, 406 y 407; Ó CONNAILL, Colm: "Irish migration to Europe in the Eighteen Century: the case of France and Spain", e igualmente ANDÚJAR CASTILLO, Francisco: "Familias irlandesas en el Ejército y en la Corte borbónica", en E. García Hernán y O. Recio Morales (coords.): Extranjeros en el Ejército..., op. cit., pp. 243 y 273 respectivamente. Igualmente recogidas sus acciones en SAÑUDO BAYÓN, Juan José: Base de Datos sobre las Unidades Militares en el Guerra de la Independencia. Ministerio de Defensa. Madrid, 2007.

${ }^{16} \mathrm{Y}$ su penúltimo un irlandés que estuvo presente en Asturias de forma muy activa, desarrollando un trato cercano con los políticos y militares del Principado: Sir William Parker Carrol. Vid. LASPRA RODRÍGUEZ, Alicia: "La intervención británica en Asturias durante la Guerra de la Independencia", Militaria. Revista de Cultura Militar, vol. 21 (2007), p. 77. Para más información, y relacionándolo además con la Brigada Irlandesa, vid. de la misma autora: "William Parker Carrol and the frustrated re-establishment of the Irish Brigade in Spain, 1809-11", The Irish Sword, XXVI/104 (2008), pp. 151-170. Por otro lado, según lo que tratamos, MORAL MARTÍN, Victoriano del: "Los últimos años del Ejército español en el Perú. Reglamentos orgánicos y tácticos. Uniformidad, banderas y estandartes”, Revista de Historia Militar, 35 (1973), p. 51.
} 
Según figura en su historial, esta unidad es de las de más solera castrense de nacionalidad irlandesa. Veneraba por patrón a San Patricio y su sobrenombre era La columna hibérnica. Si bien su vida fue breve en comparación con la de otras unidades, es de destacar algunos puntos particulares y propios. Uno sería que casi todos sus jefes, oficiales y sargentos isleños adquirieron la nacionalidad española. Como expone su historial,

"corta pero gloriosa fue la vida de este Regimiento, cuya nota más simpática es la nacionalidad española que a su solicitud adquirieron todos sus jefes y casi todos los oficiales y sargentos irlandeses, que al disolverse el cuerpo fueron a revivir en regimientos de línea".

Igualmente, buena parte de sus oficiales subalternos procedían del Colegio Irlandés de Salamanca, agregado a la Universidad, a cuyos colegiales se les estimulaba a alistarse.

\section{EL $1^{\text {er }}$ BATALLÓN DEL HIBERNIA SE UNE A LA CAUSA PATRIÓTICA ${ }^{17}$}

Un regimiento no siempre se encontraba completo en el mismo lugar, sino que podía ubicarse en distintos escenarios al mismo tiempo. Esto es, sus batallones o incluso parte de éstos, podían estar cumpliendo diferentes misiones. De hecho, como veremos, su primer batallón se "asturianizará" y pasará a servir en el Ejército del Principado (signo de total asimilación), pero, a la vez, los otros dos de que se componía quedan incluidos en la reforma de 27 de junio de 1808 llevada a cabo por Joaquín Blake, integrados en la $1^{\text {a }}$ División y contando como Comandante de la misma al Jefe de Escuadra D. Felipe Jado Cagigal.

\footnotetext{
${ }^{17}$ Aparte de la bibliografía que mostramos en el presente estudio, hay otras obras que aluden al Regimiento y su contexto irlandés, como incluso a su participación en Asturias. Como es evidente, hubimos de escoger, no podemos recoger todas debido al espacio y temática que abordamos, con lo que nos centramos aquí en puntos concretos buscando una aportación. Pero, aunque sólo sea por dejar constancia de algunas en las que aparece más o menos detalladamente la unidad objeto de nuestro trabajo, citamos, entre otras: CLONARD, Conde de: Historia orgánica de las Armas de Infantería y Caballería españolas, desde la creación del Ejército permanente hasta el día, tomo XI. Madrid, Imprenta del Boletín de Jurisprudencia, 1857, pp. 315 y ss.; GARCÍA PRADO, Justiniano: "El Muy Noble Ejército Asturiano en 1808", Revista de la Universidad de Oviedo, 24 (1947), pp. $97-$ 125; del mismo autor: "Los regimientos asturianos en la Guerra de la Independencia", en Revista de la Universidad de Oviedo, 26 (1947), pp. 65-117; FUGIER, André: La Junta Superior de Asturias y la Invasión francesa (1810-1811). Gijón, Silverio Cañada, 1989; CARANTOÑA ÁLVAREZ, Francisco: La Guerra de la Independencia en Asturias. Gijón, Silverio Cañada, 1984; MENÉNDEZ MANJÓN, Carmen: "Gijón en la Guerra de la Independencia", en Actas del Congreso Histórico Internacional de la Guerra de la Independencia y suépoca, vol. II. Zaragoza, Instituto Fernando el Católico, 1964, pp. 427-495; TORENO, Conde de: Historia del Levantamiento, Guerra y Revolución de España, Madrid, Biblioteca de Autores Españoles, 1953; BORREGUERO BELTRÁN, Cristina: "Soldados irlandeses en el Ejército español del siglo XVIII", en $\mathrm{M}^{a} \mathrm{~B}$. Villar García (coord.): La emigración irlandesa..., op. cit., pp. 101-125; o PÉREZ FRÍAS, Pedro Luis: "Unidades extranjeras en el Ejército Borbónico español del siglo XVIII”, en $\mathrm{M}^{a}$ B. Villar García y P. Pezzi Cristóbal (eds.): Los extranjeros en la España Moderna, op. cit., T. II. Málaga, Universidad de Málaga, 2003, pp. 631-643.
} 
Por nuestra parte y lo que estamos viendo, tal y como aludimos más arriba, es difícil un trabajo que descienda al ámbito personal y nominal de todo el Regimiento, con lo que nos centramos, dentro de la dificultad que conlleva, en dicho primer batallón, pues su protagonismo no pasó desapercibido en absoluto y fue de gran importancia en el Principado de Asturias. En él detectamos precisamente orígenes irlandés y extranjero en sus componentes, si bien no siempre de primera generación, aunque no fueron éstos una excepción. Es así como observamos entre sus miembros -aparte de su propio coronel o su Sargento Mayor, de quienes daremos unas líneas en breve-, apellidos como los del Ayudante Pedro de Suy, el capellán Fray Pedro O’Mannion, los capitanes Diego Clarke Cominges, Juan Drimgold ${ }^{18}$, Guillermo Livesay, Pedro Dejony, los tenientes Jaime Butler y Agustín Poncerot Dart o el subteniente de Granaderos Pedro Dalesme Bertín ${ }^{19}$.

En cuanto a los hechos, nos fijamos en lo sucedido en los albores de la gran guerra nacional. De este modo, una semana después del célebre Dos de Mayo, en Oviedo tiene lugar una sublevación por la que se hace con el poder una Junta revolucionaria. Bien es cierto que, por una división política interna, en los días siguientes pierde fuerza y no prosperará el primer intento, pero el afán conspirativo no cesó y dará sus frutos. Murat recibe estas noticias el día 17 y al momento dispone enviar desde Valladolid al Principado al Escuadrón de Carabineros Reales, al mando del Comandante Manuel Ladrón de Guevara, y al $1^{\text {er }}$ Batallón del Regimiento Hibernia. Este último, bajo el mando del Coronel Carlos Fitzgerald $^{20}$, sale el 20 de mayo proveniente de Bilbao con instrucciones de llevar a cabo una marcha forzada sin más parada que la necesaria para el descanso del soldado. Debía influir en el cumplimiento de las disposiciones sobre la recogida de armas que se habían distribuido en Asturias y ponerse a las órdenes de Juan Crisóstomo de la Llave, Comandante General de Santander -quien debía hacerse cargo de la revuelta con homónimo empleo, e imponerse como presidente de la Audiencia-. En Laredo recibe los pasaportes y una comunicación de La Llave previniéndole que debía acatar sus instrucciones a la par que le designaba los tránsitos hasta Ribadesella. Llega la tarde del 24, al igual que los Carabineros Reales, y se le indica que debía dirigirse a Oviedo, marcándole

\footnotetext{
${ }^{18}$ Su apellido original pudiera haber sido Driscoll. No obstante, apuntamos aquí que, si bien entendemos que probablemente fuera así, es cierto que lo común en las fuentes es encontrarlo como Drimgold y variantes, como en su propio expediente. Es por esa razón que aquí lo significamos de tal manera.

${ }_{19}$ Archivo General Militar de Segovia, Sección 1a 43D, exp. 0; 123D, exp. 0; 0344, exp. O; 2432P, exp. 0; 2857C, exp. 1. Archivo General de Simancas, Secretaría de Guerra, leg. 7322, exp. 159; Archivo Histórico de Asturias, Libros de Actas..., sig. 127, doc. cit., ff. 7 v. y 8 r. del mes de octubre. FERNÁNDEZ DE LA LLANA GRANDA, Juan: Banderas y Uniformes de Tropas Asturianas. Oviedo, 1980, p. 20.

${ }^{20}$ Significamos aquí que este apellido es común que nos aparezca en las fuentes en dos términos. Es decir, como Fitz-Gerald o Fitz Gerald.
} 
el reposo para la tropa. Precisamente, en la noche de ese día tiene lugar en la ciudad la sublevación definitiva comenzando con el asalto a la fábrica de armas.

El 25 de mayo de 1808 una Junta del Principado de carácter revolucionario asume la soberanía y le declara unilateralmente la guerra al Imperio así como se ratifica en la organización del llamado Ejército Defensivo Asturiano (idea del día 9 que no había podido tomar forma $)^{21}$. En tal jornada se nombra General en Jefe de tal Ejército al Marqués de Santa Cruz, Joaquín Navia Osorio, lo que coincide con el problema de enfrentarse con el Escuadrón de Carabineros Reales. Ante la llegada de éstos y sin desatender la sublevación, tomó medidas para atraerlos a su causa o inutilizarlos. Pero el desvelo duró poco, pues los soldados enviados al Principado se unieron al levantamiento, aunque su comandante fue detenido para evitar su linchamiento, pues corría el rumor de que estaba vendido a los franceses.

Por su parte, el batallón del Hibernia ofreció más dificultades de integración debido a la resistencia de sus oficiales, sobre todo la de su Coronel. Entendemos que éste es el punto más interesante, dejando de lado las cuestiones estrictamente militares, y por eso le dedicamos más espacio. Así pues, los sucesos del 24 se propagan con rapidez. El Marqués de Santa Cruz recibe las noticias de su llegada con la preocupación de que podría no adherirse a la causa nacional ya que, además, estaba compuesto casi todo de extranjeros. Ordena entonces a Fitzgerald que detuviera la tropa en Pola de Siero y que él en persona se dirigiera a la capital para tratar y resolver su fidelidad. Fitzgerald efectivamente se detiene en Pola de Siero, pero no va a Oviedo. Reúne a los oficiales en un consejo de Guerra y da instrucciones para que ni ellos ni la tropa salieran de la villa. El Consejo decide que la unidad se dirija a la capital pero sin tomar parte de los sucesos, al igual que comunicar tanto al de Santa Cruz como al gobierno de Madrid su resolución. Así, se trata de enviar sendas comunicaciones, pero el Marqués no accede a que entren en Oviedo los militares ni finalmente se remite la segunda a Madrid por temor a la interceptación de los correos. Ante este hecho, el coronel comisiona a los oficiales D. Pedro Dalesme y D. Juan Gómez para que propusieran en su nombre a la Junta que el batallón regresara a Bilbao o que pasara al Ferrol a unirse con los batallones $2^{\circ}$ y $3^{\circ}$. A la par les encarga que averiguaran quiénes conformaban el nuevo Gobierno asturiano y, con disimulo, con qué fuerzas y artillería

21 El Principado entonces se prepara para una guerra inevitable. Los imperiales lo ocuparán de forma intermitente: a mediados de mayo de 1809 durante casi un mes; de enero de 1810 hasta junio de 1811; de comienzos de noviembre de 1811 a finales de enero de 1812; y de mediados de mayo de 1812 durante casi un mes, al igual que la primera, sin lograr controlar el territorio en su totalidad. A modo general, vid. MARTÍNEZ-RADÍO GARRIDO, Evaristo C.: "Asturias ante la Guerra de la Independencia: crisis bélica de 1810 y respuesta social”, en E. C. Martínez- Radío Garrido y A. Faya Díaz (coords.): Nobleza y Ejército en la Asturias de la Edad Moderna. Oviedo, KRK Ediciones, 2008, pp. 229-245. 
contaba y si los Carabineros Reales se habían unido a la causa patriótica. Evidentemente, atendiendo a estos hechos y de ser lo que nos ha llegado sobre ellos cierto, no habría una voluntad espontánea de unirse a la sublevación y sí desconfianza acompañada de medidas de cara a un posible choque armado (entendemos también que lógicas). Pero vayamos por partes.

La Junta, ante el posible enfrentamiento entre el batallón y el pueblo, intenta atraer al primero a la causa, con lo que le envía varios comisarios ${ }^{22}$. A todo esto, le llegan los oficiales de aquél comunicando su intención de dirigirse al Ferrol o volver a Bilbao. Por su parte, el Presidente de la misma les expone la voluntad de lucha de los asturianos, que esperaban que Galicia secundara la insurrección, al igual que los Carabineros Reales ya se habían adherido a ella, apremiándoles a secundarlos. Aquí ya se les sugiere que sería muy útil contar con su colaboración para incluirlos en las nuevas unidades del Principado, a la par que se les ofrecen empleos y ascensos. En caso de que no se adhirieran a la causa nacional, les daría orden de dirigirse a Galicia, pero sin que la Junta se hiciera responsable de su seguridad. Una vez informados y concluida la reunión, ambos oficiales permanecieron seis días en la ciudad recabando información cumpliendo con las instrucciones de su coronel.

Mientras, los emisarios de la Junta contaron en su misión con la cercanía de buena parte de la oficialidad, como la de los capitanes de Granaderos D. Juan Drimgold y D. Guillermo Livesay, del Teniente D. Alonso Suárez Zuláivar y de algunos otros subalternos quienes, al parecer, en camino hacia Santander ya habían manifestado su aversión a los franceses. Tanto es así que el mencionado Livesay llegó a desafiar en presencia del cónsul imperial a un edecán del Duque de Berg, al igual que animó al Conde Calderón de la Barca para que se pusiera al frente de aquella provincia.

Al llegar al coronel la información que había encargado a Dalesme y Gómez, el Sargento Mayor D. Remigio O’Hara, el Ayudante D. Pedro de Suy y algunos capitanes les proponen la marcha a Galicia, pero no antes de tomar la ciudad siguiendo un plan de ataque diseñado por Dalesme de cara a evitar los peligros indicados por el Presidente de la Junta -medida que, evidentemente, no nos sugiere una clara anexión o convencimiento por

22 CALVO PÉREZ, José Luis: "La orgánica de los Regimientos asturianos durante la Guerra de la Independencia (1808-1814) y período de transición al reglamento de 1815”, Boletín del Real Instituto de Estudios Asturianos, 152 (1998), p. 161. ÁLVAREZ VALDÉS, Ramón: Memorias del levantamiento de Asturias en 1808. Oviedo, Imprenta del Hospicio Provincial, 1889, p. 26. MORO BARREÑADA, José Ma: "Crisis del Antiguo Régimen y revolución Burguesa (Siglo XIX)”, en J. Rodríguez Muñoz (dir. y coord.): Enciclopedia Temática de Asturias, T. 11. Gijón, Silverio Cañada, 1990, p. 274. GONZÁLEZ-POLA DE LA GRANJA, Pablo: El concejo asturiano de Gozón en la Guerra de la Independencia. Ayuntamiento de Gozón, 2008, p. 53. D. Victorio Costales, D. Pedro de la Escosura, D. Gregorio Piquero Argüelles "y a otras personas de confianza". ÁLVAREZ VALDÉS, Ramón: Memorias del levantamiento..., op. cit., p. 58. 
la causa nacional-. A Fitzgerald, que esos días tenía al batallón con las armas en la mano por lo que pudiera pasar, le pareció una operación muy arriesgada, más cuando la labor de los emisarios asturianos daba su fruto y comenzaba la indisciplina en la tropa. Así pues, tomó la decisión de dirigirse a Galicia, pero por la costa. Da orden al oficial itinerario D. Pedro Zuloaga de acercarse a Avilés, primer punto del camino, para emprender la marcha al día siguiente. Cuando se dispone a partir le comunican que tanto Zuloaga como los hombres que le acompañaban habían sido arrestados en la villa sin motivo. Entonces el coronel comprende que la Junta no iba a permitir su salida del Principado y decide reunir otro consejo de guerra. Atento a un posible enfrentamiento, se dirige al mismo aludiendo a que, como militares, debían cumplir con su deber y obedecer las instrucciones legales (que no son las de sublevación, obviamente), al tiempo que entiende que el alzamiento no podía prosperar ante las fuerzas imperiales, con lo que sufrirían un castigo vergonzoso.

Sin embargo, hubo oficiales que se mostraron partidarios de unirse al levantamiento y, respecto al cumplimiento del deber al que alude el coronel, precisamente alegan que se cumpliría mejor con el juramento prestado de ser fiel al Rey y así servir al Trono y la independencia. Pero no fueron la mayoría, que se conformó con seguir lo que dispusiese el coronel, lo que nos lleva a plantearnos si pesara, si no su indiferencia política, sencillamente el simple acatamiento del escalafón reglamentario. Aún no había concluido el consejo cuando le visita D. Nicolás de Llano Ponte, Mayor General del Ejército Asturiano. Lo recibe Fitzgerald y disuelve el consejo. Aquél le informa de que la Junta estaba enterada de lo sucedido en Avilés y que tomaría providencias sobre el asunto, pero que la unidad debía decidir qué partido tomar, pues de otro modo habría de adoptar las medidas que considerara oportunas. De no unirse a la causa, le advierte que en Oviedo había fuerza suficiente para enfrentarse a él. Toda una amenaza que hizo montar en cólera al coronel, que se reafirmó en su sentido del deber. Ante la posición de Fitzgerald se retira Llano Ponte, pero no antes de intentar sacar provecho de la simpatía de Drimgold, Livesay, Suárez, Zuláivar y otros oficiales. A través de éstos y los emisarios de la Junta, en veinticuatro horas consiguió introducir la indisciplina en el batallón y así comienzan las deserciones en la tropa que, dirigiéndose a Oviedo en pelotones de treinta y cuarenta hombres, se va poniendo a las órdenes del Marqués de Santa Cruz. Quedaron en la Pola la mayor parte de los oficiales con el coronel, con lo que ya nada podía hacer Fitzgerald.

El Alférez Mayor del Concejo, D. Ramón García Bernardo, aprovechó la situación, tomó cien hombres escogidos y con otros llegados de Oviedo arrolló la guardia del coronel. Se apoderó de sus armas, la bandera y caja, lo arrestan junto a su mayor y 
conducen a ambos Oviedo para ponerlos a disposición de la Junta, llevándolos al Palacio Episcopal hasta nueva orden. Una vez en la capital, se les ofrecieron grados y distinciones, pero los rehusaron hasta más adelante, cuando debieron aceptarlos al ser incluidos en los cuerpos del recién creado Ejército Asturiano ${ }^{23}$.

Pero aquí hemos de hacer una observación que entendemos lógica respecto a las posibles dudas. Nos planteamos que eran militares profesionales y debían cumplir con su deber, que era respetar al gobierno y disposiciones legales, dejadas por los mismos Borbones españoles y acatar las instrucciones venidas por vía reglamentaria, ante una sublevación que, al menos en sus primeros momentos, no se sabía qué rumbo podía tomar, podría verse desordenada. No obstante, a nivel general respecto al resto de oficiales y sobre todo la tropa (que tendría precisamente más componente nacional), sí podemos pensar que pudiera pesar un espíritu patriótico y no tomarían las armas contra sus propios paisanos, sino contra unos franceses ya vistos como intrusos -y contra quienes ya tenían experiencia en el campo de batalla unos años atrás-. Se trataría, evidentemente, de una disyuntiva entre "dos deberes": el de cumplir con la legalidad y las instrucciones reglamentarias, o la de defensa de la nación saltándose el primero.

El día 28 la Junta se reafirmó en su soberanía durante la ausencia y cautiverio del monarca y, entre sus medidas adoptadas, figuraban las disposiciones para que se unieran a su causa el escuadrón de Carabineros Reales y los hombres del Hibernia. Entendemos este momento como significativo en cuanto el $1^{\text {er }}$ Batallón ya será autónomo respecto de los $2^{\circ}$ y $3^{\circ}$, actuando de forma independiente -formarán por sí un Regimiento, en principio al mando del Coronel D. Eugenio Mac Crohon, quien fallecerá en la batalla de Medina de Rioseco- e, incluso, coincidiendo en ciertas acciones de combate como unidades distintas, caso de las de Valmaseda, a las que aludiremos más adelante.

\subsection{El caso del malogrado Coronel Carlos Bernardo Esteban José Fitzgerald: entre el honor y el deber}

Si hay un punto interesante y a destacar en la sublevación y adhesión del batallón del Hibernia, como vimos, es el de su coronel D. Carlos Fitzgerald. Aquí tenemos precisamente, la disyuntiva entre el sentido del deber y el honor entre las nuevas concepciones de lealtades que toman lugar en la Guerra de la Independencia respecto a las

${ }^{23}$ ÁLVAREZ VALDÉS, Ramón: Memorias del levantamiento..., op. cit., pp. 57-60. CARANTOÑA ÁLVAREZ, Francisco: "La Guerra de la Independencia (I). La Insurrección”, en A. Arias (coord.): Historia General de Asturias, T. 4. Gijón, Silverio Cañada, pp. 41 y 42. 
etapas anteriores. En el conflicto es conocido el peso del nuevo ciudadano, donde el Rey podía ser un elemento aglutinante, pero no esencial. En este caso y como vimos, aceptar o no un gobierno que surgió paralelo a la Corona, aún en su nombre, y sus disposiciones.

Este hombre tuvo una fortuna difícil que le acaba costando la vida. Nos detenemos en ciertos detalles que entendemos necesarios para comprender lo que tratamos. Apuntamos que llegó de Bilbao obedeciendo órdenes del Duque de Berg de sofocar la rebelión asturiana y que no se adhirió a ésta en un primer momento. Es en el segundo Consejo de Guerra en Pola de Siero cuando Álvarez Valdés le pone en su boca unas palabras que, bajo nuestro punto de vista, son muy reveladoras en tanto muestran la disyuntiva planteada ante un militar con un marcado sentido del deber. Y son más valiosas en tanto que, pudiendo dudar de que sean realmente fidedignas y que no lo describe como un compatriota/patriota, sí alude a tal sentido ${ }^{24}$ junto con el del honor. Por las mismas vemos un jefe militar que alude a defender la legalidad, que no sería la asturiana rebelde. Igualmente que no albergaba esperanzas de que la insubordinación prosperara y advierte de un final ignominioso en caso de apoyarla, nuevamente afectando a su honor militar. Y hemos de notar con ello que no observa ante sí a una fuerza regular, sino a paisanos armados, eso sí, sintiéndose amenazado ${ }^{25}$. Pero, sea como sea, es evidente que la situación le inquietó, con lo que debió, efectivamente, de tratar salir del Principado.

Álvarez Valdés sitúa precisamente su vacilación en su procedencia, extranjera (él declara ser de origen irlandés, "pero" nacido en los Estados de Austria), que contrasta con la del Comandante de Carabineros Reales Ladrón de Guevara, pues sus orígenes eran españoles. Por nuestra parte nos planteamos si lo que le hubiera pesado fue precisamente tal sentido del deber y la disciplina en un militar realmente veterano; contaba 69 años. Y aquí destacamos un hecho, aparte de los sucesos que acabamos de ver. Según su expediente matrimonial, sabemos que era hijo de un teniente coronel (pesando entonces la tradición militar aludida) y, tanto su padre como su madre, habían muerto en el mismo año de 1777 cuando residían en Polonia al servicio de aquél rey. Por tanto, a modo de hipótesis, sospechamos de una muerte violenta, lo cual pudiera influir en su carácter y en los aspectos que tratamos ${ }^{26}$. Otra cuestión es si el exceso de celo (sin entrar en si podía ser algo patológico) paradójicamente no siempre era lo correcto o, al menos, lo más práctico, como veremos unas líneas más adelante.

\footnotetext{
24 Si bien chocaría con el patriotismo y la causa nacional y, por tanto, es relativo.

${ }^{25}$ En este punto y en caso de tomar las armas, entendemos que tampoco sería realmente honorable luchar contra campesinos (que no defienden la legalidad y que finalmente serían aplastados).

${ }^{26}$ Archivo General Militar de Segovia, Sección 1ª leg. F-1485.
} 
Por otro lado, contamos y contrastamos sus propias declaraciones del mes de junio, teniendo en cuenta que estaba cautivo. Según éstas, había salido de Bilbao desconociendo el motivo. Cumplía simplemente con las instrucciones que se le daban sin saber realmente cuál era su misión o siquiera planteárselo (obediencia ciega del cumplimiento del deber). En este punto, si bien puede parecernos curioso, coincidiría con Álvarez Valdés cuando expone que las iba recibiendo en el camino. Sin embargo, lo que nos puede plantear más dudas es su comportamiento en el Principado. Esto es, alude a que respetaba las órdenes del Marqués de Santa Cruz, reconociendo entonces su autoridad militar, que no era otra que la surgida de una Junta revolucionaria y, por tanto, ilegal. Aquí es fácil que se disparen las hipótesis, más si no contamos con más testimonios al respecto. Así, podemos sospechar de su vacilación o no reconocimiento a la misma en tanto no haber obedecido la orden de aquél de dirigirse a Oviedo desde Pola de Siero. En este punto entendemos que podía haber dejado a su unidad al mando de un segundo. Bien es cierto que debía estar en alerta por lo que pudiera suceder en un terreno que mostraba síntomas de zozobra e inestabilidad en sentido hostil. Sin embargo, en estas declaraciones expone que sí era proclive a la revolución y sentía aversión por los franceses, aunque debía ser prudente. Entendemos que dio un argumento lógico; no cabía otro, fuera cierto o no. Igualmente alude a desconocer las órdenes y llegada de los Carabineros desde Valladolid o la de los otros apresados junto a él. Estas dudas o sombras le acabarán costando muy caro.

Pero sin dilatarnos más en su carácter, ante su irresolución fue reducido a prisión en el castillo-fortaleza de Oviedo junto con Ladrón de Guevara y el Capitán General de la Costa Cantábrica Juan Crisóstomo de la Llave, donde se hubo de colocar por las noches un fuerte destacamento para su seguridad debido a los ánimos exaltados del pueblo. La Junta del Principado les perdonó la vida buscando alejarlos de la provincia al tener ocasión a través de Gijón. No obstante, el día 19 de junio, con la colaboración de un nuevo y desordenado Regimiento de Castropol y en medio de un tumulto, son cogidos por la fuerza y llevados hasta el parque de San Francisco para ser linchados. Allí, sin que la Junta lo pudiera impedir, comenzaron a atarlos a unos robles junto con José Antonio Mon y Velarde, Conde del Pinar, y Juan Meléndez Valdés -este último fue el único de los acusados de afrancesados que, tras ser liberado, efectivamente se alineó en las filas proimperiales-. Al ver llegar ya su muerte, solicitan confesión, a lo que condescienden los amotinados. Gracias a ello, llegaron unos religiosos del Convento de San Francisco para prestarles el sacramento. El contraste de la ciudad, D. José Ramón Sierra, tuvo entonces una idea salvadora. Le solicitó al canónigo D. Ildefonso Sánchez Ahumada que suplicara al Obispo 
que llevara desde la Catedral al Santísimo Sacramento en procesión hasta el lugar. Así se hace, portando el propio Ahumada la Cruz de la Victoria. Ante la vista de ello, se calmaron los ánimos y los patriotas les concedieron el perdón en nombre del Dios de la misericordia.

Al día siguiente se buscó depurar responsabilidades del motín, en el cual el oficial de Granaderos del Hibernia Guillermo Livesay había tratado de poner orden sin éxito. Se decide ponerlos en libertad finalmente el 26 de julio.

Una vez liberado se unió a la sublevación. Le fue conferido por la Junta del Principado el mando del Regimiento de Infiesto el 5 de enero de 1809 y el empleo de Brigadier el 18 de febrero del mismo año. No obstante, no acabaron ahí sus problemas. Como vimos, era un militar con un notorio sentido de la disciplina. En este punto, intentó obligar a un soldado a comer el rancho en cumplimiento de orden general comunicada al Ejército. Ante su firmeza de carácter el asunto debió tomar un cariz realmente peligroso, ya que "para salvarle la vida es preciso todo el valor de los oficiales y darle diferente destino" ${ }^{27}$. Al estar Galicia invadida y por las habilidades del militar, la Junta lo nombra Cuartel Maestre General de la División del Eo. Separado ya del Regimiento de Infiesto, fue destinado a las órdenes del general José Vorster Servet en calidad de $2^{\circ}$ jefe de la $5^{a}$ División, quien operaba desde principios de enero en tal línea. El 10 de marzo llega a San Tirso de Abres procedente de la Vega de Ribadeo y es reconocido por el paisanaje armado, quien a gritos dice: “jes el coronel del Hibernia al que quisieron matar en Oviedo!”. Es llevado a la prevención de la localidad, desde donde comunica su desdicha al general Vorster, "temiendo por la seguridad de mi vida, pues es evidente que el paisanaje me tiene en mala opinión"”28, en donde fallece el día 16 quedando abiertas las sospechas sobre que realmente fuera asesinado.

\subsection{E1 Hibernia "asturianizado"}

Una vez ya dispuesta su anexión a la causa patriótica, a finales de mayo de 1808, contando con una reducida parte de jefes, oficiales, sargentos y cabos, pero con la totalidad de la tropa del $1^{\text {er }}$ Batallón del Regimiento de Infantería de Hibernia y bajo pie de un único batallón, se constituyó en Oviedo un Regimiento que, en recuerdo de su origen, adoptó el antiguo nombre de Hibernia. Su mando lo asumió el Sargento Mayor de aquél, Remigio O’Hara. El resto de la oficialidad, sargentos y cabos del Batallón se distribuirá entre los 20

${ }^{27}$ FERNÁNDEZ GONZÁLEZ, José: ;Asturias! De Oviedo a Covadonga..., op. cit., p. 50. ÁLVAREZ VALDÉS, Ramón: Memorias del levantamiento..., op. cit., pp. 77-81, 83.

${ }^{28}$ Incluso en los documentos dirigidos a José Cienfuegos por José Vorster en esos días. Archivo Personal de José Luis Calvo Pérez. 
nuevos regimientos asturianos que se van a ir creando entre junio y agosto de 1808 , de cara a formar sus cuadros de mando ${ }^{29}$. El Mayor General Sir James Leith, llegado a Asturias fundamentalmente para recabar información, envió minuciosos informes al Vizconde Castelreagh, Ministro de Defensa, del War Office. En uno de 13 de septiembre le comentaba que

"el único tipo de fuerzas regulares del que en el momento de su declaración contra Francia (y que nunca aumentó) consistía [en] unos 450 o 500 hombres del Regimiento Hibernia, junto con unos 700 del Regimiento de Milicias de Oviedo. Los integrantes del primero de estos cuerpos, tanto soldados como oficiales, se distribuyeron casi inmediatamente ente los distintos contingentes de paisanos para darles instrucción, con la excepción de poco más de 100"30.

Así, tal componente humano proveniente del Hibernia ayudó a la instrucción, estuvo presente en las planas mayores y aportó soldados a los nuevos regimientos como pudieran ser el de Candás y Luanco, Infiesto, Lena, Ribadesella o Salas, entre otros. Por tanto, sus hombres se dispersaron y se verán afectados por las operaciones y reestructuraciones de tales unidades durante el conflicto. Con ello, vemos que el 2 de junio, el Ministerio de la Guerra de la Junta del Principado presenta un proyecto por el que los oficiales, sargentos y cabos del $1^{\text {er }}$ Batallón del Regimiento Hibernia que no hubieran quedado formando el cuerpo del mismo nombre pasarían a los cuadros de mando de los distintos regimientos asturianos ${ }^{31}$. El 21 de junio las compañías de Granaderos y Cazadores del batallón del Hibernia forman la escolta del Procurador General del Principado, D. Álvaro Flórez Estrada. También constituyeron hombres del Hibernia la Guardia de Honor de la Junta el 28 de junio, al mando del comandante con grado de Coronel D. Guillermo

\footnotetext{
${ }^{29}$ Por su parte, José Priego incluye en la incorporación a los cuadros además de quien nos ocupa, a oficiales retirados, alumnos de la Universidad Literaria y los jóvenes mejor dispuestos. CALVO PÉREZ, José Luis: "La orgánica...", op. cit., pp. 161-163. PRIEGO FERNÁNDEZ DEL CAMPO, José: "Los Regimientos asturianos en la Guerra de la Independencia”, en Militaria. Revista de Cultura Militar, vol. 21 (2007), p. 91. Si bien según Álvarez Valdés y Carantoña Álvarez serían 22 nuevos regimientos, pero no todos fueron finalmente formados. En lo que hace a la movilización, se alistó un $5 \%$ de la población asturiana, a los que se sumarían los miles de campesinos que se integraron en el cuerpo defensivo popular llamado Alarma. Una movilización ingente porcentualmente superior a la de la Francia revolucionaria. CARANTOÑA ÁLVAREZ, Francisco: "Asturias en la Guerra de la Independencia. Operaciones militares en el Principado", Militaria. Revista de Cultura Militar, vol. 21 (2007), p. 38. Sobre el caso concreto de la Alarma, vid. FUGIER, André: "Les 'alarmas' asturiennes pendant la guerre de l'Indépendance", Bulletin Hispanique, XXXII/1 (1930); MARTÍNEZ-RADÍO GARRIDO, Evaristo C.: La Alarma asturiana ante la ocupación francesa de 1810. Madrid, Fundación Cultural de la Milicia Universitaria, 2009.

${ }^{30}$ Llegó a Gijón el 30 de agosto de 1808 y permaneció en la zona que se le había asignado (no sólo Asturias, aunque fuera su base fundamental) hasta finales de noviembre. LASPRA RODRÍGUEZ, Alicia: "La intervención británica...", op. cit., pp. 69 y 70.

${ }^{31}$ Junto con los del Regimiento Provincial de Oviedo. CALVO PÉREZ, José Luis: "La orgánica...”, op. cit., p. 162. Del mismo autor: "La indumentaria militar de los regimientos asturianos durante la Guerra de la Independencia (1808-1814)", Boletín de la Academia Asturiana de Heráldica y Genealogia, 4 (2004), p. 33.
} 
Livesay. Precisamente esta Guardia de Honor conservó la uniformidad de aquél ${ }^{32}$. En 1809 la Guardia de Honor es reorganizada y queda formada por dos compañías: una de españoles provenientes de los regimientos de la guarnición del Principado y otra de extranjeros provenientes del Hibernia ${ }^{33}$.

Sin tardanza, los efectivos de esta procedencia comenzaron sus acciones militares. En un primer momento, los granaderos del Hibernia salieron a liberar Santander a las órdenes del General D. Nicolás Llano Ponte, recientemente ocupado por el General Merlé, junto con el Regimiento Provincial de Oviedo, el cuerpo de Literarios y mil hombres más al mando de D. Juan Drimgold. No obstante, no se trató más que de un paseo militar, pues el francés se retira y los asturianos emprenden el regreso sin enfrentamiento. Tras la derrota de Medina de Rioseco (14 y 15 de julio de 1808), el Principado sabía que iba a ser atacado y comienza su plan de defensa en el que, por supuesto, figuraron los hombres de la unidad que tratamos. El 24 de septiembre de 1808 la Junta dispone que con los restos del Regimiento Hibernia mas la agregación de seis compañías, se forme un nuevo cuerpo que, para distinguirlo del Hibernia de Galicia, debería tomar el nombre de Infante D. Carlos. Cuatro días más tarde aparece dirigiéndose a las Vascongadas y, junto con otras unidades asturianas, se incorpora entre el 11 y 12 de octubre al Ejército de Galicia en Quincoces (Burgos), que pasa a denominarse Ejército de la Izquierda (R.O. de 2 de octubre de ese año), bajo mando del general D. Joaquín Blake y Joyes. Según el estado Estado de fuerza de las tropas de Asturias que forman parte del Ejército de la Irquierda desde el 8 de octubre, el Hibernia (así aparece todavía en este momento denominado, figurando como su Brigadier Remigio O'Hara O'Connor) contaría con 14 oficiales y 544 hombres de tropa ${ }^{34}$. Tenemos a sus hombres, junto con los del Provincial de Oviedo, Salas, Cangas de Tineo y Lena en Villarcayo, según partes de Vicente María de Acevedo de 19 y 28 de ese mes. La unidad está entonces reagrupada en la $2^{\mathrm{a}}$ Brigada $^{35}$ bajo mando del Mariscal de Campo D.

\footnotetext{
32 Según la Gazeta de Oviedo de 29 de julio de 1808, estaba conformada por 500 granaderos de tal unidad -tal cifra resulta muy abultada y, como apunta Calvo Pérez, probablemente se trate de un lapsus tipográfico, ya que la plantilla inicial consistía en 50 granaderos al mando de un capitán-. Como nota ilustrativa, diremos que sus colores regimentales asignados por el Reglamento de 1805 eran, a saber: casaca y cuello celeste; solapas, vueltas y portezuelas anteadas; calzones y chaleco blancos y botón plateado con la inscripción Hibernia.

33 Según parece, a ésta (al igual que a otras unidades asturianas) se le proporcionó entonces suministros de vestuario de procedencia británica, de la misma remesa que la suministrada al Regimiento Infante D. Carlos. CALVO PÉREZ, José Luis: “La orgánica...”, op. cit., p. 162. Del mismo autor: “La indumentaria...”, op. cit., p. 39.

34 A fecha de 12 de octubre, según estado de las fuerzas asturianas de Nicolás Llano Ponte, con el visto bueno de Vicente María Acevedo, el Regimiento Hibernia estaba compuesto por 2 batallones con 15 jefes y oficiales y 544 soldados. Archivo Personal de José Luis Calvo Pérez; CALVO PÉREZ, José Luis: "La orgánica...”, op. cit., p. 167. ÁLVAREZ VALDÉS, Ramón: Memorias del levantamiento..., op. cit., pp. 48 y 88.

35 Álvarez Valdés por su parte dice que a la Segunda División del Ejército, que estaba en Orduña.
} 
Gregorio Bernaldo de Quirós, como vemos el 31 de octubre, junto a las unidades que acabamos de citar, cuya fuerza total era de unos 112 jefes y 3.600 hombres de tropa ${ }^{36}$.

Volviendo a septiembre de 1808 y como acabamos de ver, se había dado orden de formación de un Regimiento con la denominación de Voluntarios del Infante D. Carlos $^{37}$, cuya base es el Hibernia y del que será su coronel el dicho D. Remigio O'Hara hasta su disolución. A este respecto, nos consta por parte de 10 de agosto de 1809 desde Villaviciosa, que se le dio tal nombre ${ }^{38}$ para distinguirlo del Hibernia que estaba en Galicia. Se formará de hecho en el mes de octubre. Alude a su creación Francisco Ballesteros en su Memoria histórica de la formación del Ejército de Asturias y su actuación hasta su integración en el Ejército de la Irquierda, como su $3^{a}$ División, redactada en 1818:

"La recluta o gente que compuso este Ejército [asturiano] fue de la juventud de los mozos del País, a excepción de la que tenía un corto Batallón del Regimiento de Hibernia que accidentalmente se hallaba en aquellas circunstancias en aquella Provincia; parte de esta fuerza se repartió en varios Cuerpos y la restante sirvió de base al Regimiento del Infante D. Carlos" ${ }^{39}$.

En Espinosa de los Monteros, si bien ya tenía esta nueva denominación, sin embargo Acevedo en sus partes se refiere a él como "Hibernia-asturiano", quizás para no confundirse o ubicarse mejor en sus componentes. Pero a fecha de 14 de diciembre de 1808 y en el estado de fuerzas de los regimientos asturianos, ya no figura el nombre de Hibernia. Contaba con 2 jefes, 37 oficiales y suboficiales y 335 hombres de tropa, curiosamente en él no aparece su coronel. En cuanto a su uniformidad, se vio favorecida por la aportación británica en enero de 1809. Entendiendo entonces que llevara la conocida casaca roja. Sabemos que se vio favorecido por la aportación británica de éstos (con la roja) llegados a La Coruña y puestos a tiempo para las fuerzas del general Ballesteros en diciembre de 1808. Así leemos en sesión de la Junta del Principado de 9 de enero de 1809

\footnotetext{
36 Estos datos contrastan con el estado de la fuerza que aludimos unas líneas más arriba, pues las cifras que nos ofrecen son de 233 oficiales y 7.600 hombres de tropa (entre el Hibernia, el Provincial de Oviedo y los de Castropol, Grado, Salas, Candás y Luanco, Luarca, Villaviciosa, Lena, Cangas de Tineo e incluyendo una partida de Artillería de 2 oficiales y 144 hombres de tropa). CALVO PÉREZ, José Luis: "La orgánica...”, op. cit., p. 168. ÁLVAREZ VALDÉS, Ramón: Memorias del levantamiento..., op. cit., p. 128.

${ }^{37}$ En su historial en unos puntos se recoge la fecha de 30 de octubre (si bien se comenzaría a formar sobre el día 4), en otros la de 22 de mayo. Sin embargo entendemos que es en octubre porque coincide con otros documentos la referencia a tal mes. Archivo General Militar de Madrid, Historiales de Unidades, Regimiento de Infantería Infante $\mathrm{N}^{\circ}$ 5, Caja 30, leg. 1/039.

38 Si bien aparece igualmente como San Carlos, que entendemos sea un error. Y, en el informe sobre el estado que presentaba en Colombres a 22 de abril de 1809, se recoge como su nombre el de Regimiento de Infantería de Linea Voluntarios del Infante D. Carlos. Documentos cortesía de José Luis Calvo Pérez.

39 Archivo Histórico Nacional, Diversos-colecciones, 136, N.16, transcrito por José Luis Calvo Pérez y de libre consulta en línea: <www.arhca.es> [ref. 29-VIII-2012].
} 
que "con los cuatro mil uniformes [rojos] venidos de Inglaterra, se vista [entre otros] al Regimiento Infante D. Carlos”,

El 5 de marzo de 1811 se funda el $1^{\circ}$ de Asturias, que recreó al regimiento de tal nombre cautivo en Dinamarca en $1808^{41}$, y en abril el $2^{\circ}$, absorbiendo al D. Carlos junto al de Candás y Luanco, Fernando VII, Luarca, Gijón, Grado, Colunga y Llanes ${ }^{42}$.

Por otro lado, si bien aludimos en su momento a que los hombres del original $1^{\text {er }}$ Batallón del Regimiento Hibernia fueron distribuidos en otras unidades asturianas, para no dispersarnos, lógicamente no aludiremos a todas y sus diferentes acciones. Únicamente rescataremos alguna alusión sobre la que conservó más tiempo el nombre de origen irlandés. Así pues, estuvo presente en las acciones de Valmaseda (Vizcaya) a comienzos de noviembre, junto con otros contingentes asturianos. Unos días después, lo vemos en Espinosa de los Monteros (10 y 11 de noviembre), donde llevó a cabo una acción de refuerzo de los regimientos de Castropol, Luarca, Candás y Luanco y Grado en la batalla que allí tuvo lugar.

Tanto el recién creado Regimiento Infante D. Carlos como los hombres del antiguo Hibernia en las unidades asturianas, tomaron parte en las acciones de Francisco Ballesteros sobre Santander de junio de $1809^{43}$ o Zamora el 1 de octubre de 1809. Del mismo modo, combatirán con sus respectivos regimientos en otras muchas a lo largo de la Guerra, actuando en lugares como Andalucía, Castilla la Vieja, Vascongadas e incluso Francia. Por supuesto y sobre todo, también en el Principado. Pero no nos detendremos en ellas por no ser demasiado latos.

Junto con ello, la presencia de los hombres del Hibernia no quedó reducida a estas expediciones, sino que los encontramos en la propia Asturias llevando a cabo las aludidas labores de instrucción y otras gestiones políticas, prueba de su integración y consideración por parte de los asturianos, caso del coronel del D. Carlos D. Remigio O’Hara. Era éste de origen irlandés y noble, como se aprecia en su expediente militar, pero realmente integrado en los esquemas españoles. Si bien vimos en su momento cómo O’Hara fue uno de los

\footnotetext{
40 Archivo Personal de José Luis Calvo Pérez, tomado del Archivo Histórico Nacional, Consejos, 11995, exp. 36; CALVO PÉREZ, José Luis: "La indumentaria...", op. cit., pp. 32 y 33. Con ello, siguiendo al mismo autor, salvo los uniformes británicos que se entregaron por esas fechas, no le consta documentación alguna acerca de la entrega de más vestuarios. Sí es cierto que Flórez Estrada había solicitado a los británicos 12.000 uniformes de color azul y divisa roja y otros 12.000 pardos con divisa verde. No obstante éstos según parece no llegaron, con la excepción de los 4.000 rojos recibidos en diciembre de 1808.

${ }^{41}$ Éste había sido creado durante la Guerra de Sucesión. Vid. MARTÍNEZ-RADÍO GARRIDO, Evaristo C.: La Guerra de Sucesión y Asturias. Consejería de Educación y Turismo del Principado de Asturias y KRK Ediciones. Oviedo, 2009, pp. 371-381.

42 También se creó el $3^{\circ}$ de Asturias, extinguiéndose en 1813. PRIEGO FERNÁNDEZ DEL CAMPO, José: "Los Regimientos asturianos...", op. cit., p. 92.

43 ÁLVAREZ VALDÉS, Ramón: Memorias del levantamiento..., op. cit., pp. 136, 165-167 y 170.
} 
oficiales que no mostró en un principio una clara voluntad de adhesión a la causa española, sí es cierto que después destacó en la misma y en el Principado,

"donde cooperó con tesón en el primer impulso que se dio del vencimiento de la lucha en que estaba empeñada la nación, con el reparto que hizo de oficiales y tropa a los regimientos nuevamente creados en el Principado en aquella crítica época para su organización e instrucción en la nueva táctica militar ${ }^{34}$.

Siendo Comandante General de la línea de Navia desde $1^{\circ}$ de marzo de 1810 hasta 5 de mayo del mismo año, por esos días lo tenemos desempeñando además distintas labores de retaguardia. Entre ellas, por ejemplo, la redistribución tanto de tropas como de tambores en campaña, inspeccionar las obras de fortificación de la línea del Navia o tratar el problema de los desertores.

No fue el único que desempeñó labores de retaguardia. Otro irlandés destacado fue Juan Drimgold, quien en 1808 será el Coronel del regimiento asturiano de Lena y a quien, entre otras actividades, lo vemos en la zona de Grandas de Salime por el mes de marzo de 1809 realizando pesquisas por posible espionaje y traición con los franceses ${ }^{45}$.

A modo de colofón, una vez visto el caso del Primer Batallón del Hibernia, sólo nos resta exponer unas breves consideraciones. En primer lugar, entendemos que fue un ejemplo de un hecho que no fue único, pero sí de gran importancia. Aquí destacamos el apoyo a la sublevación, como es evidente. Pero junto con ello, el prestado a la clase política, como se evidenció al respetar sus dictámenes (siendo reconocidos sus servicios por ésta), colaborando con ella e incluso formando la Guardia de Honor de la Junta del Principado. Por tanto, y al contrario de algo notorio en el siglo XIX español, el Hibernia no se consideró un árbitro de la política del momento, sino un instrumento de ésta.

Unido a ello, y respecto a sus raíces irlandesas un siglo después de haberse formado, es un ejemplo igualmente de cómo siguieron pesando en el Ejército español. Contó con hombres con tales orígenes, observando aquellos de primera generación que se distinguieron en sus acciones y presencia, caso de Guillermo Livesay, Juan Drimgold, Remigio O’Hara o el capellán Pedro O’Mannion. La integración hibernesa tendría dos vertientes: por un lado aquella que podríamos decir de clan, relacionado con lo atávico, con los matices que pueda haber. Aquí veríamos el caso de Carlos Fitzgerald, que se seguía considerando irlandés a pesar de haber nacido en los Estados de Austria y desempeñar su

44 Archivo General Militar de Segovia, Sección 1ª leg. O-3; Sección 1ª, 30, exps. 00, carpeta 2, y 01.

45 Archivo Histórico Nacional, Consejos, 11995, exp. 31. Archivo General Militar de Segovia, Sección 1ª, 1184D, exp. 0. Fue un jefe valeroso que fallecerá en acción en Carpio, lugar cercano a Medina del Campo (Valladolid), el 23 de noviembre de 1809. 
profesión en España. O el testimonio previo de los hermanos O’Donnel, también ligados al Hibernia, que mantenían modos y costumbres de su país de origen.

Sin embargo, no se trataba de algo excluyente respecto al de acogida. De hecho, un signo claro de asimilación del Primer Batallón del Hibernia fue el pasar a servir al Ejército asturiano, siendo sus hombres distribuidos con mando (que fue ofrecido y aceptado por los del Principado) sin ningún problema. Y recordemos, sus jefes seguidos incluso en batallas de relieve y con graves pérdidas como Espinosa de los Monteros -caso de Drimgold, quien destacó al mando del Regimiento de Lena-. Es evidente que su profesionalidad y veteranía fueron valiosas y bien aprovechadas. Asturias y la sublevación supusieron un gran impulso para los oficiales del Hibernia, pues llegaron a promocionar a las coronelías de distintos regimientos de esta tierra y se distinguieron con ellos. Junto a ello, también se dieron relaciones personales con la población local a distintos niveles -caso del mencionado Juan Drimgold, por ejemplo, mismamente en sus pesquisas sobre los espías, o de William Parker Carroll-.

También contamos con ejemplos de aquellas características generales de integración de esta comunidad expuestas a nivel general al comienzo de este trabajo. Incluso contrajeron matrimonio con españolas formando su familia (ejemplos de Remigio O’Hara o Guillermo Livesay, entre otros) asentándose en España. Con ello, nos consta una tradición militar en parte de sus componentes, evidentemente, no en todos. Entendemos que en éstos pudo ser igualmente un factor que influyera en el valor asimilación del Hibernia en la causa patriótica, quedando reflejado a su vez al incluirse en las unidades asturianas.

Otro punto sería el plantearse si la balanza se decantó por un verdadero patriotismo o por el deber castrense. Aquí, es cierto que en el momento de la sublevación los oficiales irlandeses de primera generación también se dividieron en sus fidelidades. Es decir, no parecía que en un principio pesara un sentimiento único de fidelidad, o sentido del deber. Por otro lado, en tanto sus componentes hiberneses, no sería extraño pensar en que la de la Independencia podría no ser "su guerra", no obstante, esto no fue relevante, se impuso su profesionalidad y se esforzaron en ella. Lo que sí es claro es que hubo una diferencia entre la oficialidad y la tropa, la más numerosa y que más deserta, si se nos permite, con un componente "propiamente" español. Igualmente, también es cierto que el $1^{\text {er }}$ Batallón se desentiende de los $2^{\circ}$ y $3^{\circ}$, por lo que le pesó más el espíritu rebelde, o de causa, que el corporativismo o sentimiento de pertenencia a su regimiento, del mismo modo con componente isleño, como es obvio. 
Sea como sea, por el presente trabajo rescatamos su dedicación a la causa nacional, a la cual sin duda ayudaron, tanto con su sangre como por la instrucción y organización profesional de la que hicieron alarde.

\section{Apéndices}

Palabras del Coronel D. Carlos Fitrgerald al segundo Consejo de Guerra en Pola de Siero por boca de Ramón Álvarez Valdés

Señores, el honor de VV. es el mío y de todo el Regimiento de mi mando. No hay género de sacrificio que no esté resuelto a hacer por conservarle; y no ha habido paso alguno que no hubiese dado para que no se mancille. Hace más de cuarenta años que sirvo en la carrera militar, y en ella creo haber cumplido con este sagrado deber. Los acontecimientos de la provincia nos tienen en la alternativa de obedecer las disposiciones de la Junta o las del Gobierno que dejó el Rey establecido. Yo creo que no hay que dudar de la decisión que debemos tomar, porque la obediencia es la base fundamental de la disciplina militar, y en ella están cifradas las grandes acciones de la milicia. La orden con que hemos venido a Asturias fue dada por aquel que el Rey mismo mandó obedecer, y faltaremos a ella si nos adherimos a la insurrección de esta provincia. Es preciso advertir, señores, que hasta ahora ninguna otra la imita; que en Burgos hay un Cuerpo de ejército francés de seis mil hombres, sin contar con otros que marcharon sobre Madrid; y que una división que se destaque sobre el país, sofoca su agitación, haciendo que el paisano se repliegue a su casa. ¿Qué será, pues, de nosotros en este caso? Es indudable que los oficiales seremos todos juzgados militarmente y fusilados con ignominia. Yo entre tanto trato de que no se nos atropelle, y la actitud en que tengo el batallón con las armas en la mano, no es más que para evitarlo, pues que los emisarios que vienen de Oviedo, nos acaban de amenazar. Del mismo modo es la contestación que da airado a Llano Ponte ante la amenaza de ser aplastado: “...Haga V. presente en mi nombre a los señores de la Junta que el batallón Primero de Hibernia siempre cumplirá con su deber conservando el honor a todo trance" 46 .

${ }^{46}$ ÁLVAREZ VALDÉS, Ramón: Memorias del levantamiento..., op. cit., pp. 59 y 60. 
Declaración del Coronel del Regimiento Hibernia D. Carlos Fitzgerald tomada en el Real Castillo Fortaleza de Oviedo en junio de 1808

Respondiendo D. Carlos Fitzgerald a las preguntas ordinarias que los Comisionados le hicieron, dijo:

Ser originario de Irlanda, nacido en los Estados del Imperio de Austria, su edad 69 años cumplidos, casado y Coronel del Regimiento (de) Infantería de línea Hibernia.

Y a las demás que asimismo se le hicieron, contestó:

Que el día 20 de mayo último, a su parecer, salió de Bilbao con su batallón de orden del Excmo. Sr. O’Farril, Ministro de la Guerra, para pasar a esta capital y ponerse bajo de las órdenes del Comandante general de la costa de Santander D. Juan Crisóstomo de la Llave, sin darle a entender el motivo de su traslación de dicha villa de Bilbao a esta ciudad con su batallón, porque los superiores en iguales casos no manifiestan a los inferiores las causas que en ellas influyen, ni su objeto.

Que el día que a trozos salieron los soldados de la Pola para esta ciudad sin bandera, ellos se fueron sin su permiso, quedando la bandera y la caja en la casa de posada donde se hallaba alojado, pues no podía salir de aquel lugar con dicho batallón a causa de haber recibido orden de S. E. el señor Marqués de santa Cruz, General en Jefe, para mantenerse en él hasta que otra se le comunicase.

Que, sin embargo de haberle insinuado este señor viniese a verse con él dejando el batallón en la Pola, no lo hizo como se lo manifestó, primeramente por hallarse indispuesto, y también porque no quería abandonar el batallón en la crítica situación en que se hallaba, y antes hubiera deseado que no le hubiese detenido S. E. en la citada villa, pues que, viniendo con el batallón, hubiera manifestado los sentimientos de su corazón a favor de Fernando VII. Que esto lo prueba la confianza que ha hecho al Sr. Nicolás de Llano Ponte, General de División de la provincia, en las varias veces que fue a visitarle a la referida villa, a quien dijo que actualmente no era tiempo de declararse por ser preciso ver lo que hacían las demás provincias, especialmente Galicia, donde tenía sus dos batallones, que le obligaban a estar a la mira de su conducta, añadiéndole que era de la mayor importancia una vez que no podía declararse en el momento, y que se le dejase neutral en la Pola, pues, si llegaba el caso de atacar a los franceses la provincia, se declararía al instante a favor de Fernando VII. 
Que no es presumible fuese otra su conducta cuando a su mujer usurparon los franceses de los Bancos de Génova en la última guerra ${ }^{47}$ cien mil pesos, quedando desnuda de facultades; y otros motivos mayores que les asisten para mirar con total odio las máximas de la Francia.

Que la única noticia que tuvo de la llegada del escuadrón de Carabineros Reales fue en los tránsitos, especialmente en Ribadesella, pero que ignora el objeto de su comisión y también la del Sr. La Llave. Que la única correspondencia con éste ha sido por haberle remitido un pliego a Laredo a su salida de Santander, con el que iba el pasaporte expresivo de los tránsitos que en su ruta debía hacer hasta Ribadesella, donde debía aguardar sus órdenes, como lo ejecutó.

Que no conoce a los señores Conde del Pinar y Meléndez Valdés ni sabe acerca de su comisión cosa alguna. Que no se le pidió juramento de fidelidad a su soberano. Que le ofreció de palabra y aún por memorial a la Suprema Junta de la provincia de estar pronto a hacerle hasta derramar la última gota de sangre por Su Majestad ${ }^{48}$.

${ }^{47}$ Estaba casado con $\mathrm{D}^{\mathrm{a}}$ Teresa Centurión Aldobrandi, de orígenes nobles genovés y corso. Archivo General Militar de Segovia, Sección $1^{\mathrm{a}}$, leg. F-1485.

48 ÁLVAREZ VALDÉS, Ramón: Memorias del levantamiento..., op. cit., p. 209. Realizamos alguna corrección gramática y ortográfica. Evidentemente esto contrasta con lo que comenta este autor en su relato, quizás para darle un sentido más patriótico a su discurso. 